\title{
Patient's rights and doctor's rights: HIV-infected physicians and dentists on the cut edge
}

\author{
SCOTT H. ISAACMAN, DO, JD
}

Media, professional associations, public health agencies, legislators, and courts have focused attention to the problem of HIV-infected healthcare professionals. Practitioners should become aware of recently revised ethical guidelines, the doctrine of informed consent, court decisions, and legislation because of the effects these events have on practice and because patients will pose questions on these issues.

(Key Words: HIV, healthcare professionals, informed consent, ethics, law)

Ordinarily, the licensing of dentists and physicians occurs without regard to whether the doctor has an infectious disease. In some circumstances, such as hospital employment and military service, ${ }^{1}$ periodic physical and laboratory examination are regularly performed. Generally, the regulation of professional conduct relies on subjective reporting and incident occurrence. No restriction of practice occurs unless the practitioner self-reports and volunteers to limit activities, a peer reports an-

Dr Isaacman is staff physician, Cook County Department of Health, Sexually Transmitted Disease Division, Maywood, Ill, and adjunct professor, The John Marshall Law School, Chicago, Ill.

This paper formed part of a presentation titled, "A Debate on Mandatory Testing of Health Care Professionals," in a continuing medical education program, HIV AIDS: Practical Approaches for Health Care Professionals, by the University of Toronto, Toronto, Canada.

Reprint requests to Scott $H$. Isaacman, DO, JD, The John Marshall Law School, 315 South Plymouth Ct, Chicago, IL 60604 . other's impairment, or a patient becomes infected through contact with a healthcare professional. These subjective and post-hoc approaches have failed to allay public concern regarding infected doctors. Politicians have responded with legislation that proposes several innovations: HIV testing for all healthcare professionals (HCPs), serostatus disclosure by those who test positive, and practice restrictions for those who are seropositive.

The infectious conditions of HCPs were once a private matter. Few such infections were incurable and life-threatening. All of this changed in light of the AIDS epidemic. ${ }^{2,3}$ Episodes of HIV transmission from a dentist to patients in Florida ${ }^{4}$ have popularized suggestions for mandatory HCP HIV testing and modification of the practices of those who are seropositive. Proposed practice guidelines have been issued by the American Osteopathic Association (AOA), Centers for Disease Control (CDC), the American Hospital Association (AHA), the American Dental Association (ADA), the American Medical Association (AMA), state medical associations, state legislators, federal legislators, and state licensing boards. This article briefly reviews the risks infected HCPs pose to patients, the "patient's right to know," and the ability of agencies to require testing. The article then discusses recent ethical guidelines and legislative proposals.

\section{Risks posed to patients}

A decade into the HIV epidemic, the public 
remains hysterical about HIV transmission. Because there is documented transmission of HIV from patient-to-HCP, ${ }^{5} \mathrm{HIV}$ transmission from HCP-to-patient was also thought possible (this has been inappropriately referred to as "reverse transmission," a clear misnomer). When the CDC unveiled medical evidence detailing transmission from a dentist to patients, ${ }^{6}$ this possibility became reality. Neurologic impairment, the other well-known hazard of HIV disease, has yet to receive much current attention. Clinicians recognized this problem early in the history of the AIDS epidemic. ${ }^{7}$ Initially, when the media focused on this facet of the disease, some employers removed HIV-infected employees from positions of responsibility in an attempt to avoid potential injury of others. ${ }^{8}$ Once again, these same concerns about HIV-infected HCPs are quietly being voiced by professionals. ${ }^{9}$

\section{The right to know a doctor's HIV status}

Vociferous arguments abound concerning the patient's right to know HCPs' HIV status. The origin of this right is emotional. Patients feel that they should have the right to avoid placing themselves at risk of a deadly terrifying disease. No doubt patients have a right to be informed about risks concurrent with medical procedures and treatment, but the physician's HIV status should have no relevance to procedures and treatment. If one's being seropositive adds an avoidable risk to medical procedures and treatment, then such a risk must be eliminated.

This avoidance of risk is not, however, the patient's responsibility. The same government officials who provide professionals with licenses to practice are tasked with ensuring that those licensees practice in a manner that does not harm the public. State licensing agencies are empowered to "revoke, suspend, place on probationary status or take any other disciplinary action as the Department may deem proper," 10 regarding licensees. Most agency regulations contain broadly worded subsections covering physician impairment. For example, the Illinois medical licensing agency regulations allow disciplinary action "for physical illness, including, but not limited to ... , which results in a physician's inability to practice medicine with reasonable judgment, skill or safety." 11 This language already covers HIV infection because the infection may make the performance of some invasive procedures less safe and neurologic sequelae may affect both judgment and skill. New HIV-specific regulations seem superfluous.

Nevertheless, proposed HIV-specific regulations may give patients a right to know personal information about HCPs instead of addressing any administrative agency shortcoming. From a public health perspective, the responsible way to eliminate this risk is through action by those agencies tasked with that responsibility and supported by tax dollarsnot through individual doctor-patient disclosure and selective patient judgment. A patient's judgment might not be so selective when a doctor is needed.

A patient has the right to know whether or not his or her doctor is licensed to practice and whether or not the doctor has any special expertise. Being licensed by the state implies being competent to engage in clinical practice. Impaired clinicians, as judged by a group of experts rather than by prejudiced laymen, should not have the same license to practice as unimpaired professionals. There is no need for doctors to disclose personal information to the public.

\section{Mandatory HIV testing of healthcare professionals}

State agencies have very broad authority in the public health arena. States can require children receive vaccinations ${ }^{12}$ and physical examinations ${ }^{13}$ before entering public school. ${ }^{14}$ States can require marital applicants be tested for syphilis ${ }^{15}$ and HIV, ${ }^{16}$ and have physical examinations ${ }^{17}$ before receiving marriage licenses. Nothing prevents state licensing boards from requiring HIV testing as a component of license application or renewal.

A court challenge to regulations requiring HIV testing would likely fail, because courts give considerable deference to agencies. ${ }^{18}$ The Supreme Court has rebuffed challenges to public health regulations from $1905^{19}$ to the present. In a recent challenge to the Department 
of Health and Human Services's (DHHS) restriction of advice doctors may render to patients, ${ }^{20}$ the Supreme Court supported the agency's restriction of speech. Surely, the same Court would support the same department's (the CDC is under the DHHS) restriction of HIV-infected HCPs' practices if such a case would arise. When the laws requiring testing have changed, the changes resulted from legislative modification and not judicial invalidation. $^{21}$

\section{Published standards}

Concern about HIV transmission risks prompted several prominent organizations to evaluate the problem, to publish guidelines, and to issue position statements addressing HIV-infected professionals. The AOA's House of Delegates grappled with this problem and adopted resolution $242 \mathrm{~A}$ on July 20,1991 . The resolution recognizes the public health importance of AIDS and resolved that the AOA should support legislation and public health and private professional initiatives to test physicians and others at risk for the transmission of the HIV. Other organizations do not directly advocate testing of health professionals.

The most influential institutional response, the CDC's new guidelines, state:

- Exposure-prone procedures should be identified by medical, surgical, dental organizations and institutions at which the procedures are performed.

- HCWs [Healthcare workers] who perform exposureprone procedures should know their HIV antibody status. HCWs who perform exposure-prone procedures and who do not have serologic evidence of immunity to HBV from vaccination or from previous infection should know their HBsAg status and, if that is positive, should also know their HBeAg status.

- HCWs who are infected with HIV or HBV (and are $\mathrm{HBeAg}$ positive) should not perform exposure-prone procedures unless they have sought counsel from an expert review panel and been advised under what circumstances, if any, they may continue to perform these procedures. Such circumstances would include notifying prospective patients of the healthcare worker's seropositivity before they undergo exposure-prone invasive procedures. ${ }^{22}$

This document followed extensive scientific research and testimony. Yet, the quoted recommendation has little to do with science and even less to do with logic. The recommenda- tion suggests HIV-infected HCPs notify "prospective patients of the healthcare worker's seropositivity before they undergo exposureprone invasive procedures." Why inform persons seeking care for some medical disorder about their health care provider's illness? If an HIV-infected person poses a risk to patients, then that risk should simply be eliminated. If there is no risk posed by the HCP's care, then there is no legal, moral, or ethical principle to support a disclosure of such personal information. Apart from the concern of the doctor's privacy, people go to healthcare facilities either to get well or to stay well. Disclosing the medical histories of all healthcare facility employees having patient contact bears no relevance to achieving that goal.

In 1988, the AHA issued the following guidelines concerning HIV-infected healthcare workers:

As with all other potentially impaired healthcare workers, decisions about whether symptomatic HIV-infected healthcare workers can adequately and safely perform patient care duties requires consideration on an individual basis.

Hospitals should establish a mechanism to evaluate ... whether the employee known to be HIV infected can adequately and safely perform patient care duties and, if indicated, to suggest changes in work assignments. Periodic reevaluation of the symptomatic HIV-infected employee should be provided. ${ }^{23}$

This approach focuses on defining the risks posed by individual HCPs. Unfortunately, this poses administrative problems because each institution must go through lengthy individual hearings, even though there is little geographic variation in HCP practices. Another weakness to this approach is the apparent inability to safeguard HCP privacy. With the "look back" procedures and with simple hospital gossip, ${ }^{24}$ the community soon learns of the doctor's disease.

The ADA and the AMA approached this problem of HIV-infected doctors from another angle. Both organizations tried to placate the public and practitioners. The ADA stated: "HIVinfected dentists should refrain from performing invasive procedures or should disclose their seropositive status." 25 Similarly, the AMA stated: "HIV infected physicians should either abstain from performing invasive procedures 
which pose an identifiable risk of transmission or disclose their seropositive status prior to performing a procedure and proceed only if there is informed consent." 26

There are several problems with the ADA and AMA recommendations. Both recommend that HIV-infected professionals refrain from performing invasive procedures. This makes sense. Yet, both groups also approve of HIVinfected professionals performing invasive procedures if the HCP discloses his or her serostatus to patients. This does not make sense.

The AMA's Ethical Council advises doctors that it is unethical to knowingly expose patients to the physician's infectious disease. ${ }^{27}$ Beyond ethical guidelines, courts have held physicians ${ }^{28}$ and dentists ${ }^{29}$ liable for the transmission of infectious diseases to patients. ${ }^{30,31}$ Yet, according to the organizations' statements, doctors may subject patients to such risks if the patient consents.

There is no ethical or legal foundation for suggesting that HIV-infected HCPs can perform procedures that may result in the transmission of HIV to the patient if the patient willingly accepts that risk. Surgical procedures carry inherent risks. Informing patients about such risks is the foundation of informed consent. Adding a risk not native to the procedure itself unjustly adds a risk to the patient. No one would accede to a proposed operation where the surgeon was blindfolded. Patients need not face such frivolity. Any risk posed by an HIV-infected HCP can be avoided by substituting another physician or dentist.

There is no benefit to the patient from adding an avoidable risk, and there is no public policy that supports this position. Adding such a risk devalues respect for patients and human life. Medical ethics demand placing the consideration of patients before concerns of an infected physician's livelihood. ${ }^{32}$ Similarly, courts have never approved of Russian roulette.

Informed consent is a legal principle. Courts, not the ADA or the AMA, define the required elements. Justice Blackmun defined informed consent as "the giving of information to the patient as to just what would be done and as to its consequences." ${ }^{33}$ This defini- tion does not include any reference to additional risks arising from who performs the procedure or why that individual's performance would increase the chances for adverse consequences.

To suggest HIV-infected physicians adopt a novel form of consent that adds an avoidable physician-dependent risk is cavalier and open to legal challenge. A court may invalidate the consent after hearing a full discussion about the effect of the patient's medical condition, the influence of the personal relationship with the doctor, and the social policy of not allowing individuals to take unnecessary life-threatening risks. There is no precedential legal support for validating the new consent recommendations.

The ADA's and the AMA's suggestions also fail to consider the reality of practice. Although the professional has a duty to maintain the confidences of the patient, there is no reciprocal patient duty. Immediately after the doctor's HIV status disclosure to the patient, the patient can contact local or national media with impunity. What will that do to the doctor's practice?

None of the resolutions refute the claim that patients have a right to know a doctor's serostatus. This right may appeal to public passions and the "tit for tat" sense of justice, but it is a liberal invention without legal foundation. Furthermore, if the doctor follows the other sections of the resolution and no longer performs risk-bearing activities, then there is no basis to suggest the patient has a right to know.

\section{Developing legal principles}

A handful of legal cases involving HIV-infected HCPs commenced before the report of the Florida dentist. These decisions show how courts address challenges to institutions' employment and educational practices related to persons infected with HIV. Future decisions will undoubtedly take into consideration the CDC report of HIV transmission from HCP to patients.

One of the earliest cases ${ }^{34}$ involved an HIVinfected physician in Illinois. Cook County Hospital initially terminated the physician's di- 
rect patient care activities. The physician sued, alleging violation of federal handicap laws that protect employees in institutions receiving federal funds from unjust discrimination. The physician claimed that the dismissal was unjust because he posed no identifiable hazard to patients. The hospital claimed he posed a theoretical hazard and the consequences of that hazard justified removal from clinical activities. The HIV-infected physician won a temporary injunction against the institution's change in clinical privileges. Before a final hearing, the parties settled the matter by entering into a consent decree that permitted the physician to engage in all of his direct patientcare activities, which required him to adhere to the CDC's universal precautions, and which required double-gloving with certain procedures.

To date, only one case, ${ }^{35}$ from Nebraska, invalidated an HIV-testing policy. In that case, a state agency issued a personnel policy requiring employees in a facility for the mentally handicapped to periodically test for hepatitis B and HIV. Nurses, licensed practical nurses, and others who came into direct patient contact were to be tested, ostensibly because of concern that patients who were violent or aggressive might bite or scratch an employee and thereby contract hepatitis B or HIV from the infected employee. Coincidentally, immediately before the policy's promulgation, an employee of the agency died of AIDS. Of note, the employees never engaged in the performance of invasive medical procedures with the mental patients.

The trial court and the appellate court held that the testing policy violated the rights of the employees to be free from unreasonable searches and seizures under the Fourth Amendment to the United States Constitution. ${ }^{35}$ These courts concluded that there was no reasonable basis for the testing program because the medical evidence described the risk of a patient's contracting HIV from an employee as "miniscule, trivial, extremely low, extraordinarily low, theoretical, and approaches zero."

In two other cases, courts upheld hospitals' actions against a suspected HIV-infected employee and against an HIV-infected surgeon.
In a Louisiana case, the hospital fired a nursing staff employee who refused to provide the institution with his HIV test results. ${ }^{37}$ This government hospital became suspicious that a gay employee, whose lover was hospitalized for an AIDS-related illness, might also be infected. Some of the employee's job functions included changing dressings, starting intravenous lines, and giving injections. The hospital demanded the employee submit to an HIV test and furnish it with the results. When the employee refused, the hospital suspended and then fired him for insubordination.

Relying heavily on existing CDC guidelines, AHA guidelines, and expert medical testimony, the court concluded that the hospital did not violate federal or state handicap laws or constitutional provisions. The court interpreted the existing guidelines to mean that it was necessary for the hospital to know if the employee was infected with the HIV in order to monitor his situation and to consult with his physician so as to be able to advise the employee to protect his own health and the health of patients.

The Louisiana court distinguished its case from the Nebraska case on the basis of the testing requirement's scope. Nebraska issued a broad policy covering all employees, whereas the Louisiana hospital's HIV testing involved a specific person with suspected HIV infection.

Recently, a New Jersey court upheld a hospital's denial of surgical privileges to an HIVinfected otolaryngologist. ${ }^{24}$ The surgeon had operating privileges at the institution until he was diagnosed as having AIDS at the same institution. His privileges were suspended, although the hospital momentarily considered allowing the surgeon to continue his surgical practice if his patients were notified of his AIDS condition and then knowingly gave informed consent.

In a 75-page opinion, the trial judge concluded that the hospital's restriction of the AIDS-infected surgeon's privileges was justified because of a reasonable probability of patient harm. The court emphasized three key facts in determining the hospital did not act in an unlawful, discriminatory fashion. First, medical authorities acknowledged that there 
was a small quantifiable risk of transmission of HIV from surgeon to patient. Second, HIV infection is deadly. Third, the due process requirement was met because the hospital undertook extensive investigation, discussion, and debate about this situation before terminating the surgeon's privileges.

Another area of concern, institutional policies regarding HIV-infected students, arose in a Missouri case ${ }^{38}$ when a school denied reenrollment to a dental student entering his senior year. The university justified its actions on the basis that the senior year involved clinical study and that the HIV-infected student would pose a health risk to his patients in the dental clinic. The student's handicap discrimination claim was dismissed by the judge on the basis that the infection rendered the student no longer qualified to safely engage in clinical dentistry.

The Rehabilitation Act allows for discriminatory actions where the individual "has a currently contagious disease or infection and who, by reasons of such disease or infection, would constitute a direct threat to the health or safety of other individuals or who, by reasons of the currently contagious disease or infection, is unable to perform the duties of the job."39 The newly enacted Americans with Disabilities Act ${ }^{40}$ contains similar language. Although only dental schools have published their problems with HIV-infected students, ${ }^{41}$ the same problem and principles are sure to arise with medical students and residents.

The guidelines of the health professional organizations and the case opinions indicate that many believe in a danger of HCP-to-patient transmission of HIV. National experts from the CDC estimated the magnitude of this risk. ${ }^{42}$ Courts acknowledge that although the statistical risk of such transmission is very slight, the potential result is so terrible as to justify legal recognition and reasonable precautions. The ADA policy, the AMA policy, and the court opinions point out that HCPs who engage in invasive procedures are the focus of appropriate concern. In contrast, where the HCPs did not conduct invasive procedures, testing was deemed inappropriate and a violation of HCPs' constitutional rights. ${ }^{43}$
The report of the Florida dentist with AIDS will surely change the policies of educational institutions toward HIV-infected students along with the policies of institutions where physicians and dentists practice. Even though this is not the first published case of HIV in HCPs, nor the first case to be followed by lawsuits, ${ }^{44,45}$ the case stimulated federal and state legislators to propose HIV testing of all HCPs.

\section{Governmental activity}

Federal legislation now requires states act to incorporate the CDC recommendations into their public health laws if they wish to continue to receive federal funds. ${ }^{46}$ Unfortunately, the CDC's choice of wording is open to a variety of interpretations. The federal agency's recommendation states: "HCWs who perform exposure-prone procedures should know their HIV antibody status." "Should," in legal use, is precatory and not mandatory. However, in the broad discretion of administrative agencies, this word could easily be interpreted as "must." Furthermore, without the manpower and ability to distinguish between licensees' clinical activities, these agencies may simply decide to test all licensed professionals.

State legislatures are also addressing the problem of HIV-infected HCPs. ${ }^{47}$ The primary issue is the restriction of "invasive procedures" and the notification of patients. Illinois' law includes retrospective notification of patients for contacts "who have undergone invasive procedures performed by an HIV infected health care provider." 48 Despite their expense and lack of utility, ${ }^{49}$ look-back studies are now mandatory in Illinois. Licensing agencies are also considering promulgating HIV-specific regulations regarding testing and practice. ${ }^{50}$ Where all this will end seems predictable. Once HIV infection is diagnosed, HIV-infected HCPs will no longer be able to continue their clinical practice.

\section{Discussion}

Politics, science, and law must mix when creating health policy. Groups that create position statements, professional guidelines, and legislative proposals often neglect to consider important elements from other fields. HIV- 
infected HCPs pose a challenge to healthcare institutions, licensing boards, and the courts. But, HIV infection represents only a small fraction of the conditions causing HCP impairment. Focusing solely on HIV and requiring everyone to be tested for HIV is a disjointed, short-sighted, convenient solution that plugs a leak in the dam and ignores all the other structural imperfections.

To formulate rational policies concerning HIV-infected HCPs and impaired HCPs, members of the health professions need to act in conjunction with members of the legal profession and legislators. The goals are clear: to develop comprehensive policies that protect patients and safeguard livelihood and privacy interests of HCPs. ${ }^{51}$ Once a rational standard constructed by a broad panel of experts is in place, courts, legislators, and the public may accept this suggested standard of care. To date, the approaches fail to consider broader issues, threaten the integrity of practice, and foster mistrust between patients and their physicians.

\section{References}

1. Cowan DN, Brundage JF, Pomerantz RS, et al: HIV infection among members of the US Army Reserve Components with medical and health occupations. JAMA 1991;265:2826-2830.

2. Isaacman SH: The other side of the coin: HIV-infected health care workers. Saint Louis University Public Law Review 1990;9:439-494.

3. Closen ML: A call for mandatory HIV testing and restriction of certain health care professsionals. Saint Louis University Public Law Review 1990;9:421-438.

4. Centers for Disease Control: Update: Transmission of HIV infection during invasive dental procedures-Florida. $M M W R$ 1991;40:21.

5. Marcus R: Surveillance of health care workers exposed to blood from patients infected with the human Immunodeficiency virus. $319 \mathrm{~N} \mathrm{Engl} \mathrm{J} \mathrm{Med} \mathrm{1988;319:1118-23.}$

6. Centers for Disease Control: Update: transmission of HIV infection during invasive dental procedures-Florida. $M M W R$ 1991;40:377-381.

7. Levy RM, Bredesen DE, Rosenblum ML: Neurological manifestations of the acquired immunodeficiency syndrome (AIDS): Experience at UCSF and review of the literature. $J$ Neurosurg 1985;62:475-495.

8. Closen ML, Connor SM, Kaufman HL, et al: AIDS: Testing democracy-Irrational responses to the public health crisis and the need for privacy in serologic testing. John Marshall, Law Review 1986;19:835-928.

9. Smith DD: Physicians and the acquired immunodeficiency syndrome. JAMA 1990;264:452 [letter].

10. Illinois Administrative Code Title $68 \$ 1290.60$ (a)(1988).
11. Illinois Administrative Code Title $68 \$ 1290.60$ (a)(25)(1988). 12. Zucht $v$ King 260 US 174 (1922); Dalli v Board of Ed, 267 NE2d 219 (Mass 1971); McCartney v Austin 298 NYS 2d 26 (1969); Wright v DeWitt School Dist, 385 SW2d 644 (Ark 1965); Gamble v State, 333 SW2d 816 (Tenn 1960).

13. Streich v Board of Ed, 147 NW 779 (SD 1914).

14. Ill Rev Stat ch 122, para 27-8.1 (1989)

15. Ill Rev Stat ch 40, para 204(a) (1987)[repealed]

16. Ill Rev Stat ch 40, para 204(b) (1987)[repealed].

17. Peterson $v$ Widule, 147 NW 996 (Wis 1914)

18. Chevron USA, Inc v Natural Resources Defense Council, 467 US 837 (1984).

19. Jacobson $v$ Commonwealth of Massachusetts, 197 US 11 (1905).

20. Rust $v$ Sullivan, 111 SCt 1759 (1991).

21. Turnock BJ, Kelly CJ: Mandatory premarital testing for human immunodeficiency virus: The Illinois experience. JAMA 1989;261:3415-3418.

22. 137 Cong Rec S 9979 (daily ed July 15, 1991).

23. Recommendations of the Technical Panel on Infections Within Hospitals, Management of HIV Infection in the Hospital at 38, ed $3,1988$.

24. Estate of Behringer $v$ Medical Center at Princeton, $592 \mathrm{~A}$ 2d 1251 (NJ Superior Ct 1991).

25. American Dental Association: Interim policy on HIV-infected dentists, January 16, 1991

26. American Medical Association, Department of Public Information: AMA statement on HIV infected physicians, January 17, 1991.

27. Council on Ethical and Judicial Affairs of the American Medical Association: 1989 Current Opinions. Chicago, American Medical Association, 1989, p 39.

28. Fosgate $v$ Corona, 330 A2d 355 (NJ 1974); Hofmann $v$ Blackmon, 241 So 2d 752 (Fla D Ct App 1970); Jones v Stanko, 160 NE 456 (Ohio 1928); Davis v Rodman, 227 SW 612 (Ark 1921).

29. Foster v Harris, 633 SW 2d 304 (Tenn 1982).

30. Louisell DL, Williams H: Medical Malpractice, vol 2, 1990; $\S \S 17$ B.08[3],[4]; Annotation, Liability of physician for permitting exposure to infectious or contagious disease.

31. American Law Reports 1920;5:926; Annotation, Hospital's liability for exposing patient to extraneous infection or contagion. American Law Reports 2d 1987;96:1205.

32. World Medical Association: Handbook of Declarations. International Code of Medical Ethics. Farnborough, Hampshire, England, Inkon Printers Limited, 1985, pp 3,4.

33. Planned Parenthood of Central Missouriv Danforth, 428 US $52,67 \mathrm{n} 8$ (1976).

34. Doe v County of Cook, No. 87 C 888, US District Court, Northern District of Illinois, 1987.

35. Glover $v$ Eastern Nebraska Community Office of Retardation, 867 F2d 461 (8th Cir 1989).

36. 686 F Supp 243 (D Neb 1988); aff'd 867 F 2d 461 (8th Cir 1989).

37. Leckelt $v$ Board of Commissioners of Hospital District No. 1, 909 F 2d 820 (5th Cir 1990).

38. Doe $v$ Washington University, No. 88-2509-C-4 US District Court, Eastern District of Missouri, decided October 2, 1991, reported in: AIDS Policy \& Law 1991;6(19):5-6.

39. 29 USC $\$ 706(C)$ (1988).

40. Pub L No. 101-336, §103(b), 104 Stat. 327, 334 (1990).

41. Comer RW, Myers DR, Steadman CD, et al: Management 
considerations for an HIV positive dental student. $J$ Dent Educ 1991;55:187-191.

42. Bell DM, Martone WJ, Culver DH, et al: Risk of endemic HIV and hepatitis B (HBV) transmission to patients during invasive procedures. MD 59, VII International AIDS Conference, June 16, 1991.

43. Glover v Eastern Nebraska Community Office of Retardation, 686 F Supp 243 (D Neb 1988); aff'd 867 F2d 461 (8th Cir 1989).

44. Judge allows suit over AIDS and dentist, New York Times, October 29, 1990, at B10.

45. Sussman, Judge oks suit attacking doctors' privacy right, Health Week 6, 67 (June 11, 1990).

46. Public Law 102-141 to be coded at 42 USCA sec 300ee-2 (1991).
47. Hermann DHJ: State legislatures consider bills dealing with HIV-infected health care providers in face of CDC inaction. $J$ Health Hosp Law 1991;24(7):215-219.

48. Public Act 87-763 (October 4, 1991); 77 Ill Admin Code $\$ 693.40(3)(1991)$.

49. Danila RN, MacDonald KL, Rhame FS, et al: A look-back investigation of patients of an HIV-infected physician: Public health implications. $N$ Engl J Med 1991;325:1406-11.

50. Board of Medical Examiners, Policy Statement Regarding HIV Positive Physicians (June 12, 1991).

51. Closen ML, Isaacman $\mathrm{SH}$ : Reconciling public health concerns regarding HIV-infected health care professionals and the legal rights of those professionals. WD 4180 , Seventh International AIDS Conference, June 16, 1991. 